\section{Sistem Informasi Manajemen Aset \\ Perusahaan Listrik Negara (PLN) Berbasis Web \\ Pada Rayon Kuala Enok Kabupaten Indragiri Hilir}

\author{
Nori Sahrun \\ Sekolah Tinggi Ilmu Ekonomi Riau \\ Alamat : Jl. HR. Soebrantas No.57 Panam Pekanbaru ( 28293) \\ Telp : 076163237 Fax : 076163366 \\ Email : norisahrun84@gmail.com
}

\begin{abstract}
The problems that are often faced by PT. PLN is the frequent delays in managing and maintaining assets, so that the incident can cause damage to the assets of PT. PLN such as transformers, power cables, and so forth. Damage caused to the assets of PT. PLN may result in power outages in a long time, so as to disrupt the activities of the community. An effort that can be done to overcome these problems is to build a system that can warn a regular basis about the repair time or checking of existing assets. Conditions that occur today in the PT. PLN Rayon Kuala Enok is a data collection process that is still done manually, making it difficult to see the time of repair or replacement of the existing assets. Asset data collection process is still stored in the file Ms. Excel is not possible to give a warning time of repair or replacement of the existing assets. Those problems can be solved by building a new system capable of providing regular warnings about the time of repair, or check the existing assets. With the system is expected to avoid delays in the conduct and management of the maintenance of the asset which is owned by PT. PLN Rayon Kuala Enok.
\end{abstract}

Keywords: PLN, assets, Electrical, Information System Management,Web

\begin{abstract}
Abstrak:Permasalahan yang sering di hadapi oleh PT. PLN adalah sering terjadi keterlambatan dalam melakukan pengelolaan dan pemeliharaan aset yang dimiliki, sehingga kejadian tersebut dapat menyebabkan kerusakan pada aset PT. PLN seperti trafo, kabel listrik, dan lain sebagainya. Kerusakan yang terjadi pada aset PT. PLN dapat mengakibatkan pemadaman listrik dalam waktu yang cukup lama, sehingga dapat mengganggu aktifitas masyarakat. Sebuah upaya yang dapat di lakukan untuk mengatasi permasalahan tersebut adalah dengan membangun sebuah sistem yang dapat memberikan peringatan secara berkala mengenai waktu perbaikan ataupun pengecekan terhadap aset yang ada. Kondisi yang terjadi saat ini pada PT. PLN Rayon Kuala Enok adalah proses pendataan yang masih dilakukan secara manual, sehingga sulit untuk melihat waktu perbaikan ataupun penggantian terhadap aset yang ada. Proses pendataan aset yang masih tersimpan dalam file Ms. Excel tidak memungkinkan untuk dapat memberikan peringatan waktu perbaikan ataupun penggantian terhadap aset yang ada. Permasalahan tersebut dapat teratasi dengan membangun sebuah sistem baru yang mampu memberikan peringatan secara berkala mengenai waktu perbaikan ataupun pengecekan terhadap aset yang ada. Dengan adanya sistem tersebut di harapkan tidak terjadi keterlambatan dalam system informasi manajemen terhadap aset yang di miliki oleh PT. PLN Rayon Kuala Enok.
\end{abstract}

Kata kunci: PLN, Aset, Listrik, Sistem Informasi Manajemen, Web

\section{PENDAHULUAN}

Sistem Informasi Manajemen adalah kumpulan dari sub- sub system yang saling terintegrasi dan berkolaborasi untuk membantu manajemen dalam menyelesaikan masalah dan memberikan informasi yang berkualitas kepada manajemen dengan cara mengolah data dengan komputer sehingga bernilai tambah dan bermanfaat bagi pengguna, atau dengan kata lain sistem 
informasi manajemen merupakan suatu sistem informasi berbasis komputer yang digunakan oleh manajemen untuk memproses data dan memberikan informasi yang berkualitas. Salah satu Badan Usaha Milik Negara (BUMN) yang bertugas untuk mengurus permasalahan pasokan listrik yang ada di Indonesia. Sebagai Badan Usaha Milik Negara yang menjadi sumber utama dalam menyediakan pasokan listrik di Indonesia, PT. PLN memiliki beberapa aset penting seperti, tiang listrik, trafo, kabel listrik, dan lain sebagainya yang harus diperhatikan. Setiap aset penting yang dimiliki oleh PT. PLN harus di cek secara berkala untuk memastikan seluruh aset tersebut berfungsi dengan baik. PT PLN (Persero) diberi kewenangan oleh Pemerintah dan diserahi tugas semata-mata untuk melaksanakan usaha penyediaan tenaga listrik untuk kepentingan umum, serta diberikan tugas untuk melaksanakan pekerjaan usaha penunjang tenaga listrik. Dalam menjalankan tugas dan kewenangannya. Seiring dengan perkembangan zaman, Sistem Informasi merupakan hal yang sangat berperan pada saat ini baik itu dalam melakukan pekerjaan maupun kegiatan sehari-hari. Sistem Informasi merupakan sarana yang sangat menunjang dan akan sangat berguna bagi instansi yang memiliki skala kerja Kecil, Menengah maupun Besar untuk mempermudah pekerjaannya dan untuk mencapai tujuannya secara maksimal. Tanpa adanya Sistem Informasi, Suatu Perusahaan tidak akan bisa melakukan kegiatan operasionalnya dengan lebih baik. Maka daripada itu, diperlukanlah suatu Sistem Informasi yang sekaligus dapat memanajemen kegiatan-kegiatan operasional perusahaan tersebut. Agar nantinya terdapat Kegiatan Operasional yang terstruktur dan baik pelaksanaannya.

\section{METODE PENELITIAN \\ Desain Global}

Desain global merupakan desain secara garis besar atau umum dari aliran sistem yang telah dirancang. Desain global meliputi Context Diagram, Data Flow Diagram, serta Entity Relationship
Diagram. Adapun desain global yang ada pada sistem pengelolaan dan pemeliharaan aset mesin pembangkit listrik yang akan dibangun yaitu sebagai berikut:

\section{Context Diagram}

Context Diagram merupakan sebuah diagram yang akan menggambarkan sistem pengelolaan dan pemeliharaan aset pada PT. PLN Rayon Kuala Enok secara garis besar. Adapun gambaran mengenai Context Diagram pada sistem informasi manajemen aset pada PT. PLN Rayon Kuala Enok adalah sebagai berikut:

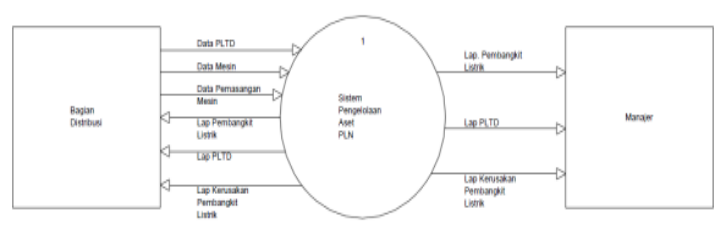

\section{Gambar 3.3 Context Diagram}

Tugas dari manajer hanya untuk melihat laporan yang telah di inputkan oleh bagian distribusi. Bagian distribusi bertugas untuk menginputkan dan mereview laporan dari beberapa data mengenai aset PT. PLN Rayon Kuala Enok di dalam sistem.

\section{Data Flow Diagram}

Data Flow Diagram merupakan sebuah diagram yang menggambarkan sistem secara lebih rinci jika dibandingkan dengan Context Diagram. Dapat digambarkan data store yang berfungsi sebagai acuan dalam melakukan perancangan Entity Relationship Diagram maupun perancangan database. Adapun gambaran mengenai Data Flow Diagram sebagai berikut: 


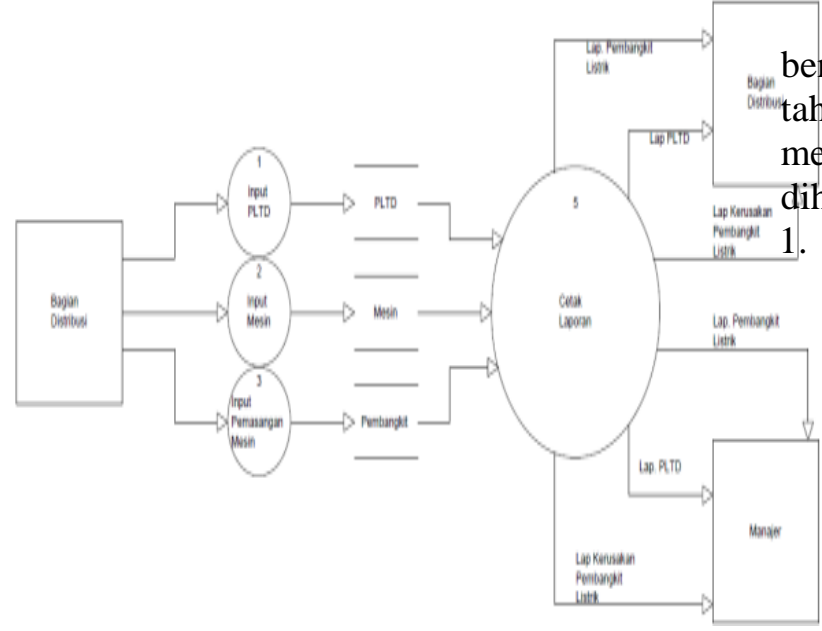

Gambar 3.4 Data Flow Diagram

Gambaran diagram tersebut merupakan penjabaran dari bentuk gambaran yang terdapat pada Context Diagram. Pada Data Flow Diagram, setiap proses yang dikerjakan oleh bagian distribusi dijabarkan satu per satu agar terlihat lebih jelas.

\section{Entity Relationship Diagram}

Gambaran yang ada pada diagram ini akan digunakan pada saat penulis membuat rancangan database. Berikut rancangan Entity Relationship Diagram yang ada pada system.
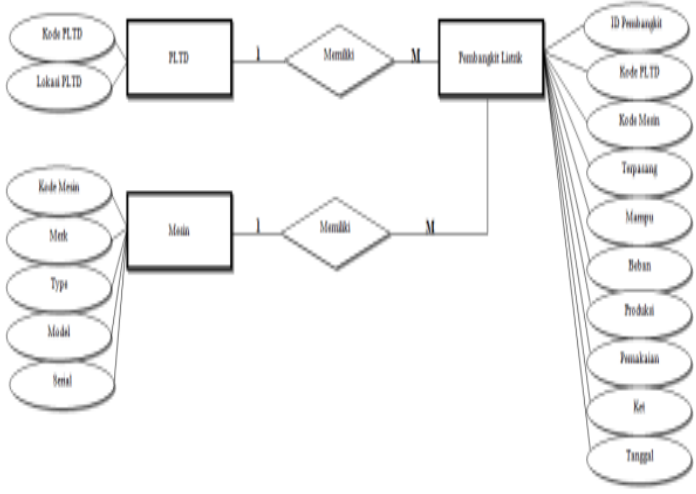

Gambar 3.5 Entity Relationship Diagram

Berdasarkan gambar diatas ada 4 tabel utama yang nantinya akan digunakan dalam melakukan perancangan database.

Desain Terinci

Desain terinci merupakan sebuah desain yang menggambarkan perancangan sistem secara lebih rinci dari yang sebelumnya. Adapun tahapan yang terdapat pada Desain terinci terdiri dari Desain Output, Desain Input, serta Desain Database. Desain Output
Desain output merupakan suatu bentuk desain yang termasuk ke dalam tahapan desain terinci dan berfungsi untuk menggambarkan bentuk output yang akan dihasilkan pada sistem yang akan dibangun.

1. Laporan Bulanan Pembangkit Tenaga Listrik

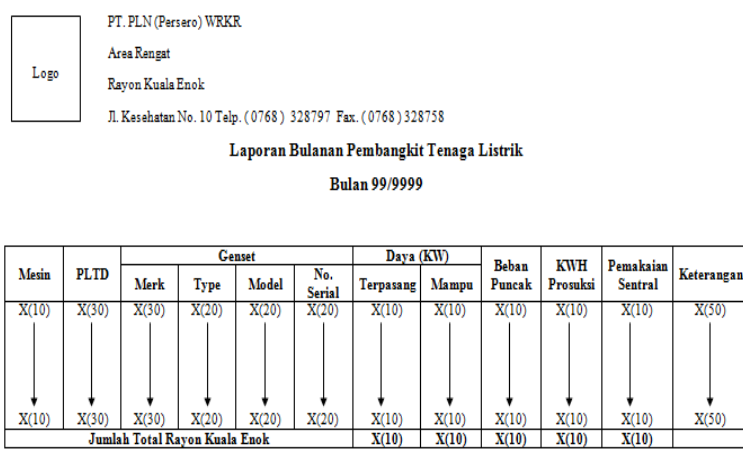

Rengat, 99:99:999

\section{Gambar 3.6 Laporan Bulanan}

Pembangkit Tenaga Listrik

Laporan ini menjelaskan mengenai mesin pembangkit tenaga listrik bulanan yang ada pada PT. PLN Rayon Kuala Enok, beserta dengan daya yang mampu di produksi oleh setiap mesin. Pada kolom keterangan berisi peringatan mengenai waktu perbaikan atau pergantian aset pembangkit listrik yang ada pada PT. PLN Rayon Kuala Enok.

2. Laporan Tahunan Pembangkit Tenaga Listrik

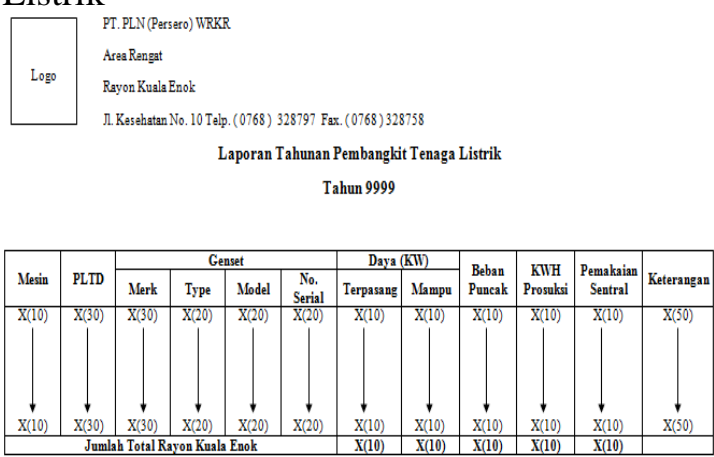

Rengegt, 999999999

\section{Gambar 3.7 Laporan Tahunan}

Pembangkit Tenaga Listrik

Laporan ini menjelaskan mengenai mesin pembangkit tenaga listrik tahunan yang ada pada PT. PLN Rayon Kuala 
Enok, beserta dengan daya yang mampu di produksi oleh setiap mesin.

3. Laporan Pembangkit Tenaga Listrik Berdasarkan PLTD

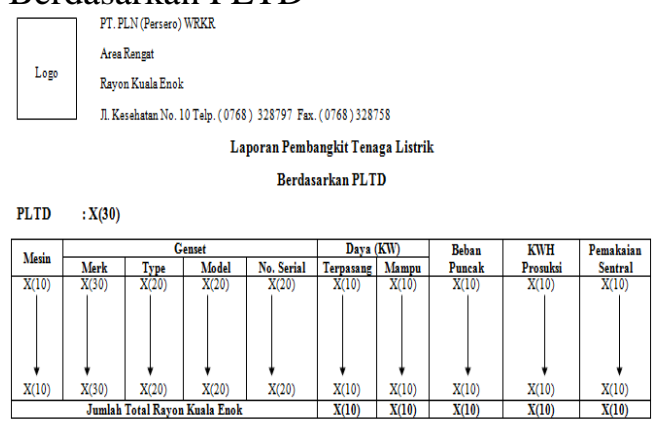

Reagat, 99999999

Manger

\section{Gambar 3.9 Laporan Pembangkit}

Tenaga Listrik Berdasarkan PLTD

Laporan ini berfungsi untuk menjelaskan setiap mesin pembangkit tenaga listrik yang ada pada setiap lokasi PLTD. Dengan adanya laporan ini manajer dapat melihat produksi KWH serta pemakaian sentral setiap mesin pembangkit tenaga listrik.

4. Laporan Bulanan Kerusakan Pembangkit Tenaga Listrik
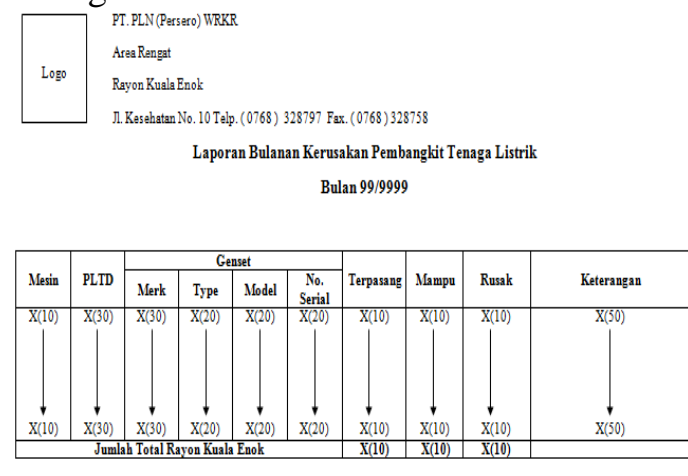

Rengat, 99:99/999

Mangier

Gambar 3.10 Laporan Bulanan

Kerusakan Pembangkit Tenaga

\section{Listrik}

Dengan adanya laporan ini manajer dapat melihat setiap mesin yang rusak dan harus di ganti.

5. Laporan Lokasi PLTD

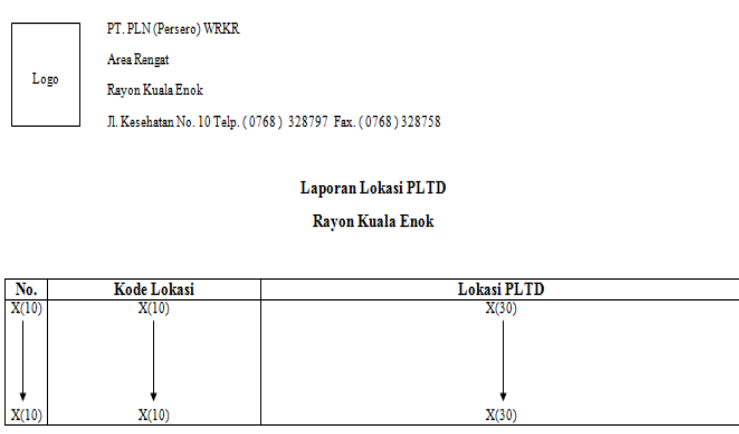

Rengat, 99.99:999

Gambar 3.11 Laporan Lokasi PLTD

Laporan ini menjelaskan mengenai lokasi PLTD yang terdapat dalam PT. PLN Rayon Kuala Enok.

Desain Input

Setelah melalui tahapan desain output, tahapan yang akan dilakukan berikutnya adalah membuat desain input untuk sistem pengelolaan dan pemeliharaan aset pada PT. PLN Rayon Kuala Enok yang akan dibangun sebagai berikut:

1. Form PLTD

Form Lokasi PLTD

Lokasi PLTD

\begin{tabular}{|l|}
\hline $\mathrm{X}(10)$ \\
$\mathrm{X}(30)$ \\
\hline
\end{tabular}

Simpan

Gambar 3.12 Form Lokasi PLTD

Form lokasi PLTD berfungsi sebagai form yang digunakan untuk menginputkan lokasi PLTD yang terdapat pada PT. PLN Rayon Kuala Enok.

2. Form Mesin

\begin{tabular}{l} 
Form Mesin \\
\hline Merk \\
Tipe \\
Model \\
Serial \\
\multicolumn{1}{|c|}{ Simpan } \\
\hline
\end{tabular}

\section{Gambar 3.13 Form Mesin}

Form mesin merupakan form yang berfungsi untuk menginputkan setiap mesin genset pembangkit tenaga listrik yang terdapat pada PT. PLN Rayon Kuala Enok.

3. Form Pembangkit Tenaga Listrik 
Form Pembangkit Tenaga Listrik

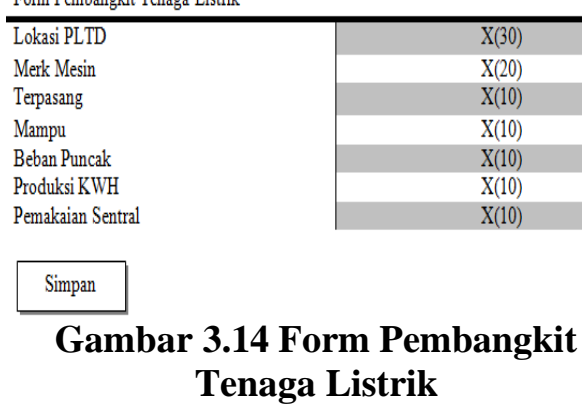

Form pembangkit tenaga listrik berfungsi sebagai form yang digunakan untuk menginput produksi KWH yang di produksi oleh PT. PLN Rayon Kuala Enok berdasarkan lokasi dan kode mesin.

4. Form User

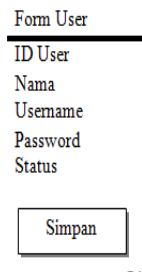

\section{Gambar 3.15 Form User}

Form user berfungsi untuk memberikan hak akses terhadap pengguna sistem pengelolaan dan pemeliharaan pada PT. PLN Rayon Kuala Enok.

\section{Desain Database}

Rancangan database yang terdapat pada PT. PLN Rayon Kuala Enok.

1. Tabel 3.1 PLTD

Nama Database : plnrayon.sql

Nama Tabel : pltd

Primary Key : kode_pltd

\begin{tabular}{|l|c|c|l|}
\hline \multicolumn{1}{|c|}{$\begin{array}{c}\text { Field } \\
\text { Name }\end{array}$} & Type & Size & $\begin{array}{l}\text { Descrip } \\
\text { tion }\end{array}$ \\
\hline $\begin{array}{l}\text { Kode_p } \\
\text { ltd }\end{array}$ & varchar & 10 & $\begin{array}{l}\text { Kode } \\
\text { PLTD }\end{array}$ \\
\hline $\begin{array}{l}\text { Lokasi_ } \\
\text { pltd }\end{array}$ & varchar & 30 & $\begin{array}{l}\text { Lokasi } \\
\text { PLTD }\end{array}$ \\
\hline
\end{tabular}

2. Tabel 3.2 Mesin

Nama Database : plnrayon.sql

Nama Tabel : mesin

Primary Key : kode_mesin

\begin{tabular}{|c|c|c|c|}
\hline $\begin{array}{c}\text { Field } \\
\text { Name }\end{array}$ & Type & Size & Description \\
\hline Kode_m & varchar & 10 & Kode Mesin \\
\hline \hline
\end{tabular}

$244 \quad$ Fakultas Teknik UMSB

\begin{tabular}{|l|c|c|l|}
\hline esin & & & \\
\hline Merk & varchar & 30 & Merk \\
\hline Type & varchar & 20 & Type \\
\hline Model & varchar & 20 & Model \\
\hline Serial & varchar & 20 & Serial \\
\hline
\end{tabular}

3. Tabel 3.3 Pembangkit Tenaga Listrik

Nama Database : plnrayon.sql

Nama Tabel

pembangkit

Primary Key : id_pembangkit

Foreign Key : kode_pltd

dan kode_mesin

\begin{tabular}{|l|c|c|l|}
\hline \multicolumn{1}{|c|}{$\begin{array}{c}\text { Field } \\
\text { Name }\end{array}$} & Type & Size & Description \\
\hline $\begin{array}{l}\text { Id_pem } \\
\text { bangkit }\end{array}$ & varchar & 10 & $\begin{array}{l}\text { ID } \\
\text { Pembangkit }\end{array}$ \\
\hline $\begin{array}{l}\text { Kode_pl } \\
\text { td }\end{array}$ & varchar & 10 & Kode PLTD \\
\hline $\begin{array}{l}\text { Kode_m } \\
\text { esin }\end{array}$ & varchar & 10 & Kode Mesin \\
\hline $\begin{array}{l}\text { Terpasa } \\
\text { ng }\end{array}$ & varchar & 10 & Terpasang \\
\hline Mampu & varchar & 10 & Mampu \\
\hline Beban & varchar & 10 & $\begin{array}{l}\text { Beban } \\
\text { Puncak }\end{array}$ \\
\hline $\begin{array}{l}\text { Produks } \\
\text { i }\end{array}$ & varchar & 10 & $\begin{array}{l}\text { Produksi } \\
\text { KWH }\end{array}$ \\
\hline $\begin{array}{l}\text { Pemakai } \\
\text { an }\end{array}$ & varchar & 10 & $\begin{array}{l}\text { Pemakaian } \\
\text { Sentral }\end{array}$ \\
\hline Ket & varchar & 100 & Keterangan \\
\hline Tanggal & date & 10 & Tanggal \\
\hline 4 Tabel 3.4 User & & \\
\hline
\end{tabular}

4. Tabel 3.4 User

Nama Database : plnrayon.sql

Nama Tabel : : user

Primary Key : id_user

\begin{tabular}{|c|c|c|c|}
\hline $\begin{array}{c}\text { Field } \\
\text { Name }\end{array}$ & Type & Size & Description \\
\hline
\end{tabular}


Vol. I No.2 Juni 2018

http://joernal.umsb.ac.id/index.php/RANGTEKNIKJOURNAL

\begin{tabular}{|l|c|c|l|}
\hline Id_user & varchar & 10 & ID User \\
\hline nama & varchar & 30 & Nama \\
\hline username & varchar & 20 & Username \\
\hline password & varchar & 20 & Password \\
\hline status & varchar & 20 & Status \\
\hline
\end{tabular}

Lakukan input data Kode ( Kode PLTD ) dan PLTD ( Lokasi PLTD ), kemudian lakukan pengecekan data. Jika data telah lengkap maka simpan dan tampilkan sebagai laporan, jika tidak inputkan data kembali.

3. Flowchart Penyimpanan Data Mesin Pembangkit

\section{Desain Flowchart}

1. Flowchart Login User
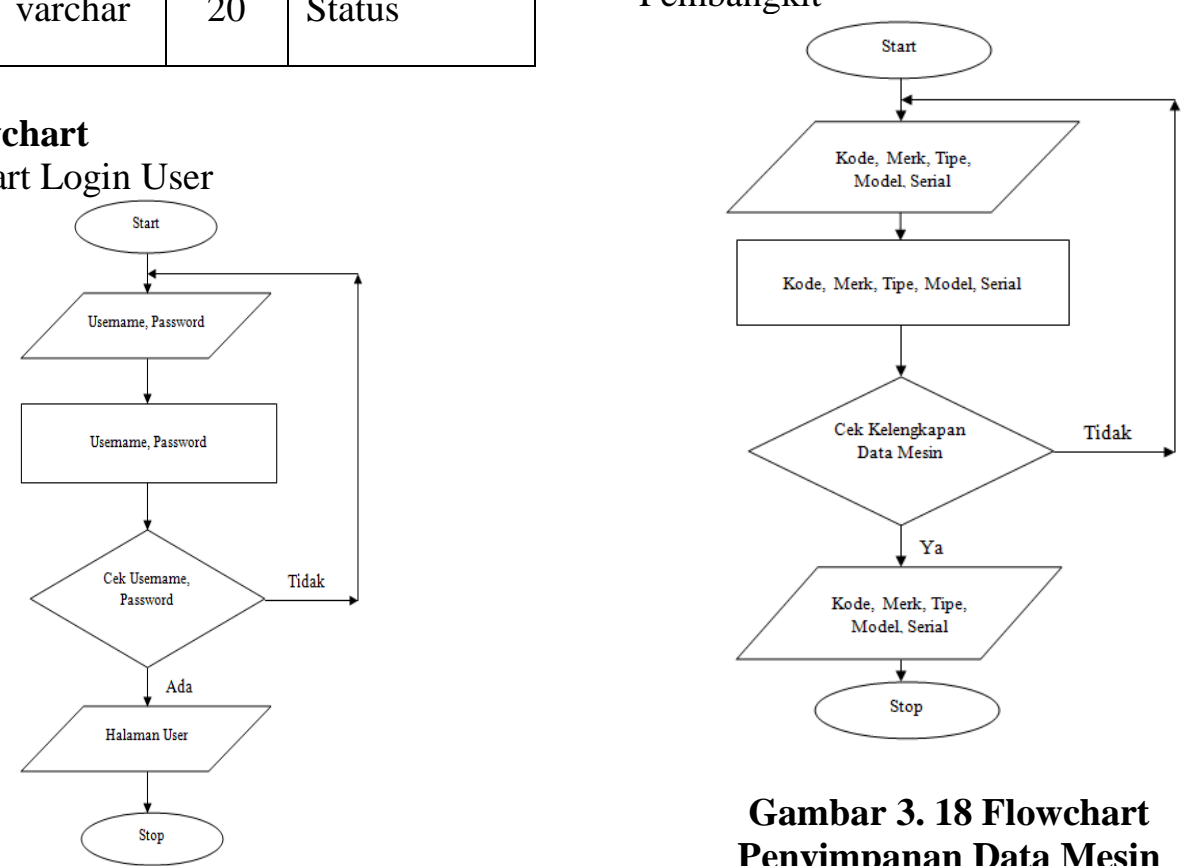

Gambar 3. 18 Flowchart

Penyimpanan Data Mesin Pembangkit

\section{Gambar 3.16 Flowchart Login User}

Saat melakukan login, user menginputkan data username dan password. Kemudian di lakukan pengecekan terhadap username dan password, jika data username dan password ada maka tampilkan halaman utama, dan jika tidak maka input username dan password kembali.

2. Flowchart Penyimpanan Data PLTD

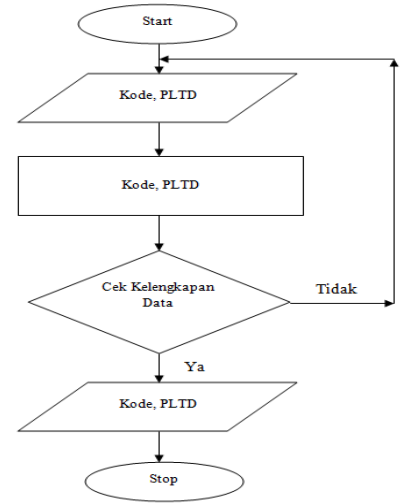

Gambar 3.17 Flowchart

Penyimpanan Data PLTD

Lakukan input data mesin pembangkit, kemudian lakukan pengecekan data. Jika data telah lengkap maka simpan dan tampilkan sebagai laporan, jika tidak inputkan data kembali.

4. Flowchart Penyimpanan Data User

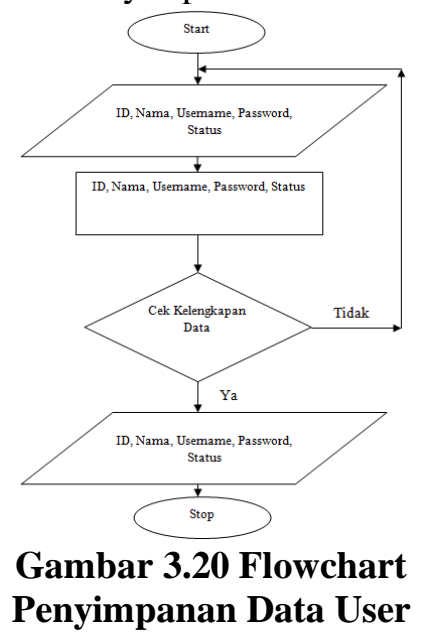

Lakukan input data mesin user, kemudian lakukan pengecekan data. Jika data telah 
lengkap maka simpan dan tampilkan sebagai laporan, jika tidak inputkan data kembali.

5. Flowchart Peringatan Perbaikan atau Pergantian Aset

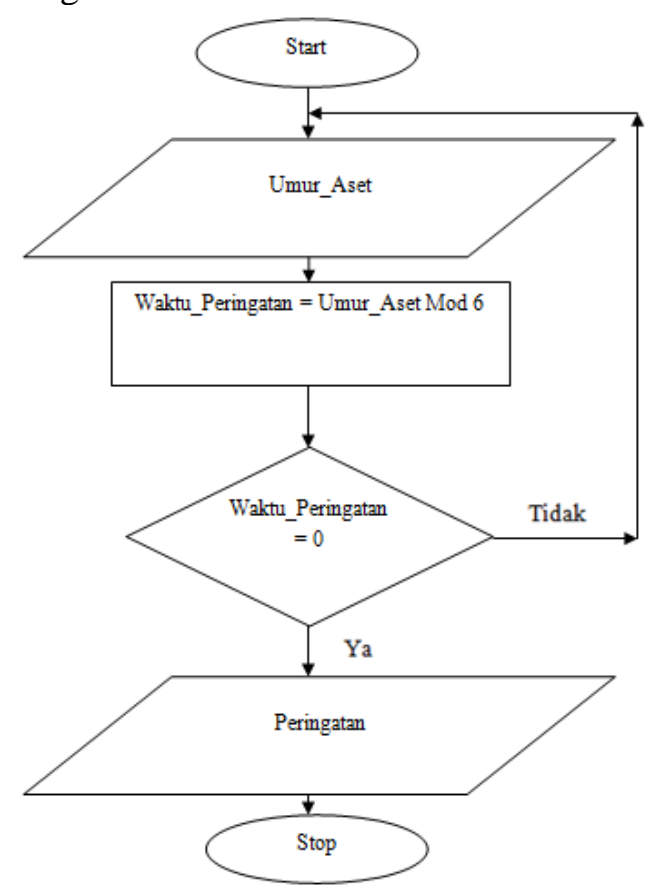

\section{Gambar 3.21 Flowchart Peringatan}

Perbaikan atau Pergantian Aset

Lakukan input umur aset dalam satuan bulan, kemudian lakukan proses modulus terhadap umur aset. Proses tersebut berfungsi untuk memberikan peringatan secara berkala, yaitu setiap 6 bulan untuk melakukan perbaikan atau pergantian aset. Jika umur kelipatan 6 bulan maka tampilkan peringatan perbaikan atau pergantian aset, jika tidak maka peringatan tidak akan tampil.

\section{HASIL DAN PEMBAHASAN}

\section{User Interface}

1. Halaman Utama
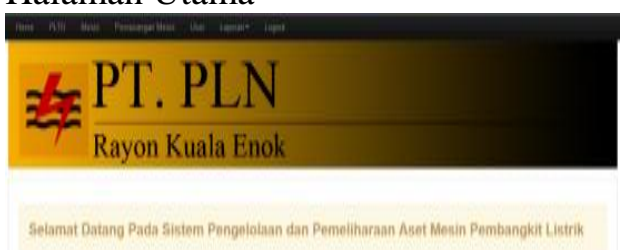

Gambar 4.1 Halaman Utama

Halaman utama merupakan sebuah menu utama yang di sediakan untuk Bagian Distribusi dan Manajer PT. PLN Rayon Kuala Enok, sehingga bagianbagian tersebut dapat mengakses beberapa sub menu yang ada.
2. Halaman Login

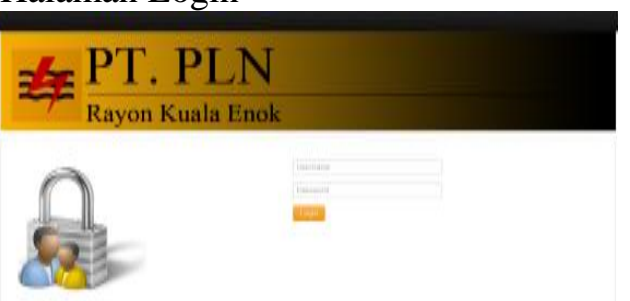

Gambar 4.2 Halaman Login

Halaman tersebut merupakan halaman yang digunakan oleh bagian distributor dan manajer untuk dapat masuk ke dalam sistem dan mengakses menu yang ada.

3. Form PLTD

Kode PLTD

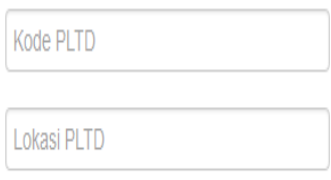

Lokasi PLTD

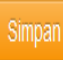

Gambar 4.3 Form PLTD

Form PLTD berfungsi untuk menginput beberapa lokasi PLTD yang termasuk ke dalam bagian PT. PLN Rayon Kuala Enok.

4. Form Mesin

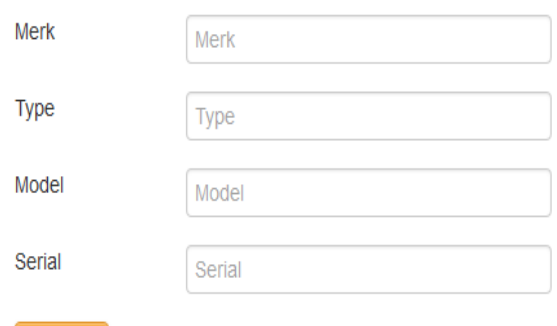

Gambar 4.4 Form Mesin

Form Mesin berfungsi untuk mendata seluruh aset mesin yang ada pada PT. PLN Rayon Kuala Enok.

5. Form Pemasangan Mesin

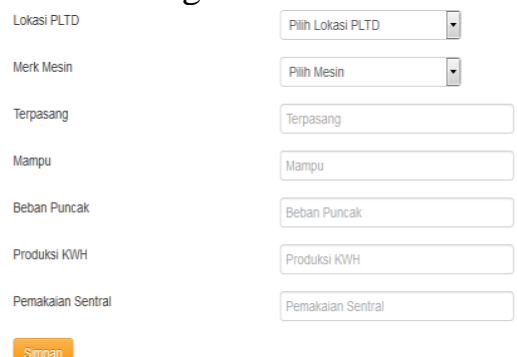

Gambar 4.5 Form Pemasangan Mesin 
Form tersebut berfungsi untuk mendata seluruh mesin pembangkit listrik yang terpasang dalam sejumlah lokasi PLTD pada PT. PLN Rayon Kuala Enok.

6. Form User

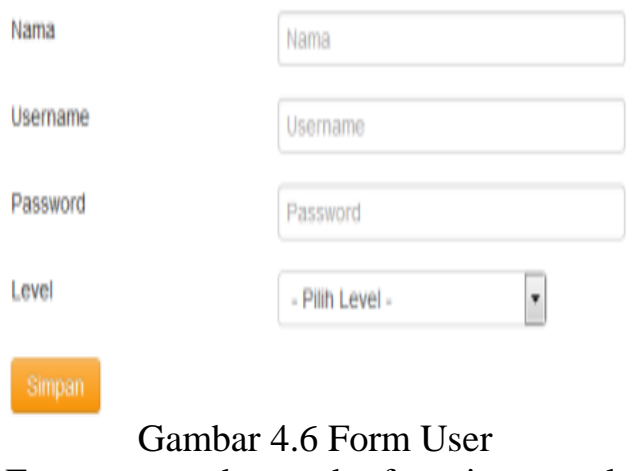

Form tersebut berfungsi untuk memberikan hak akses terhadap Bagian Distribusi dan Manajer PT. PLN Rayon Kuala Enok.

7. Laporan Bulanan Pembangkit Tenaga Listrik

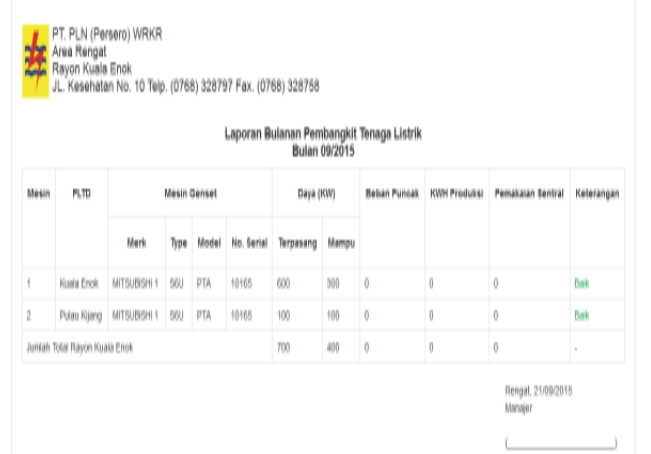

Gambar 4.7 Laporan Bulanan Pembangkit Tenaga Listrik

Laporan ini menjelaskan mengenai mesin pembangkit tenaga listrik bulanan yang ada pada PT. PLN Rayon Kuala Enok, beserta dengan daya yang mampu di produksi oleh setiap mesin. Pada kolom keterangan berisi peringatan mengenai waktu perbaikan atau pergantian aset pembangkit listrik yang ada pada PT. PLN Rayon Kuala Enok.
8. Laporan Tahunan Pembangkit Tenaga Listrik

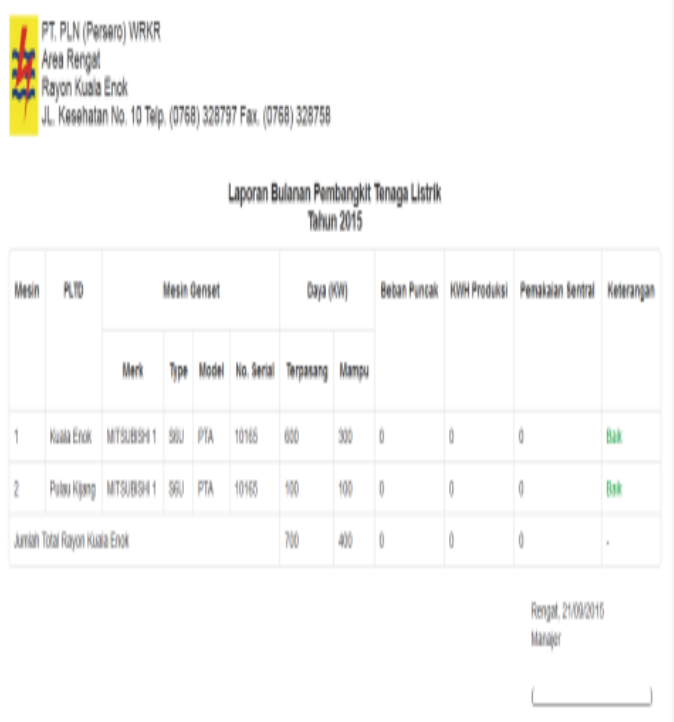

Gambar 4.8 Laporan Tahunan

Pembangkit Tenaga Listrik

Laporan ini menjelaskan mengenai mesin pembangkit tenaga listrik tahunan yang ada pada PT. PLN Rayon Kuala Enok, beserta dengan daya yang mampu di produksi oleh setiap mesin. Pada kolom keterangan berisi peringatan mengenai waktu perbaikan atau pergantian aset pembangkit listrik yang ada pada PT. PLN Rayon Kuala Enok.

9. Laporan Mesin Pembangkit Tenaga Listrik Berdasarkan PLTD

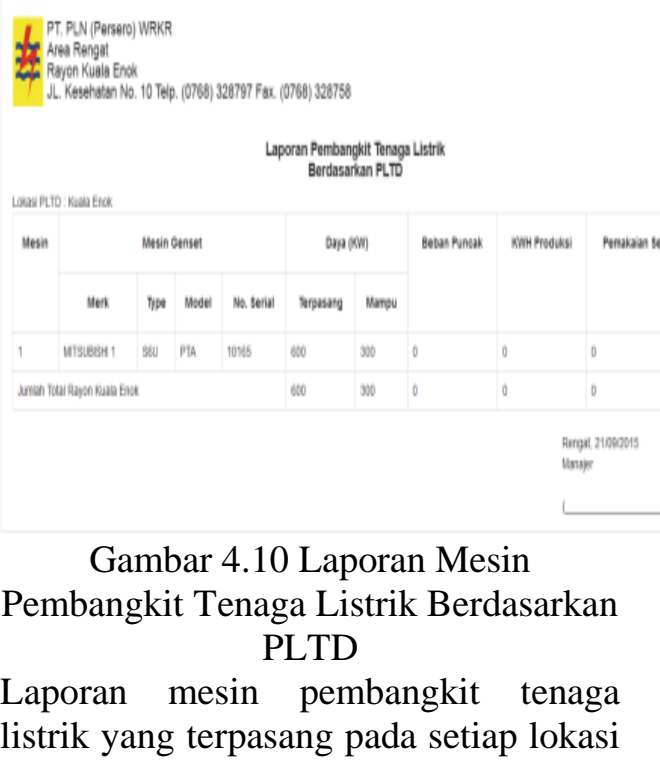


PLTD pada PT. PLN Rayon Kuala Enok.

10. Laporan Bulanan Kerusakan Pembangkit Tenaga Listrik

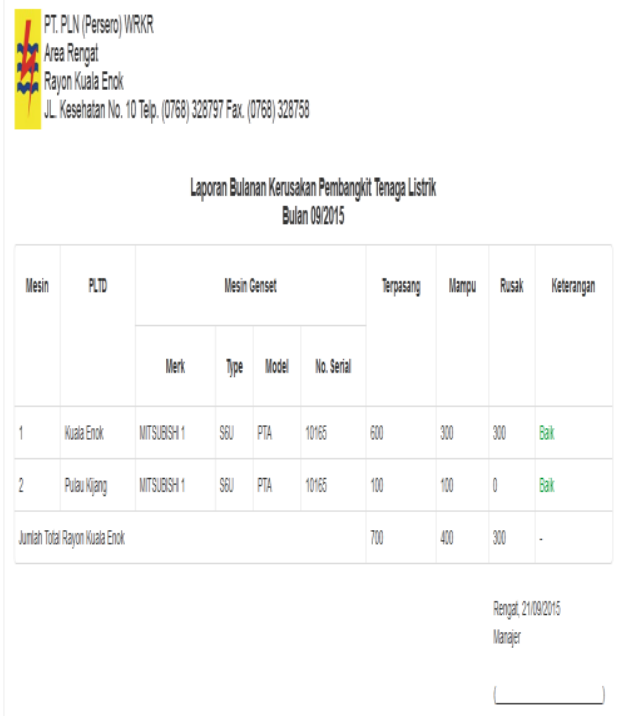

Gambar 4.11 Laporan Bulanan

Kerusakan Pembangkit Tenaga Listrik Laporan ini berfungsi untuk menjelaskan setiap kerusakan yang terjadi pada mesin pembangkit listrik setiap bulan.

11. Grafik Bulanan Pembangkit Tenaga Listrik

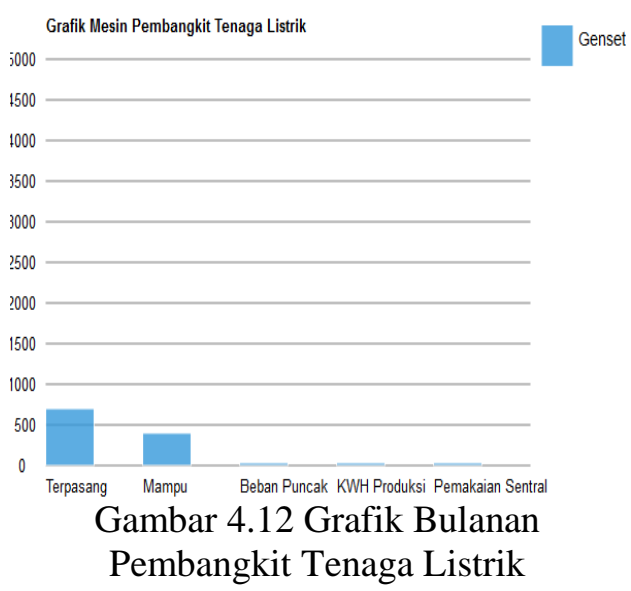

Grafik tersebut menjelaskan jumlah aset setiap bulan yang terpasang dan masih mampu beroperasi pada PT. PLN Rayon Kuala Enok.
12. Grafik Tahunan Pembangkit Tenaga Listrik

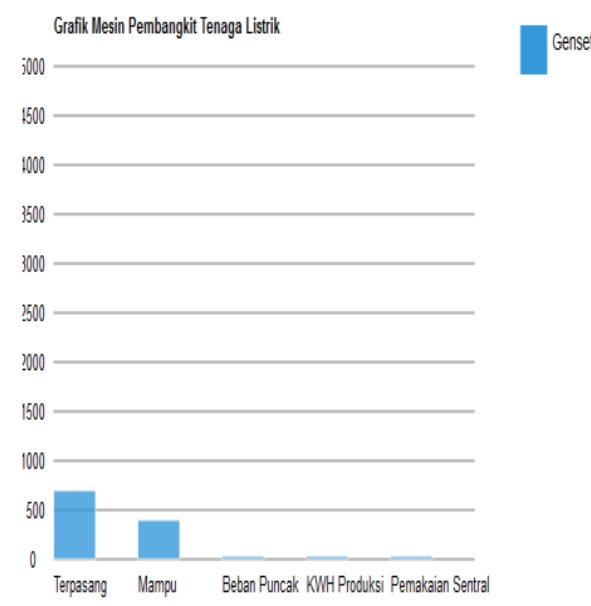

Gambar 4.15 Grafik Tahunan

Pembangkit Tenaga Listrik

Grafik tersebut menjelaskan jumlah aset setiap tahun yang terpasang dan masih mampu beroperasi pada PT. PLN Rayon Kuala Enok.

13. Grafik Mesin Pembangkit Tenaga Listrik Berdasarkan PLTD

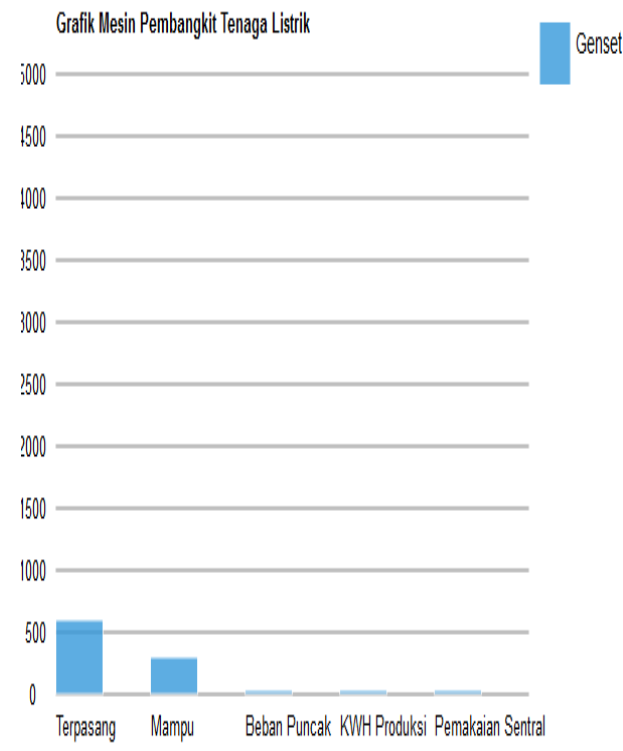

Gambar 4.16 Grafik Mesin Pembangkit Tenaga Listrik Berdasarkan PLTD Grafik jumlah aset yang terpasang dan masih mampu beroperasi pada setiap lokasi PLTD di PT. PLN Rayon Kuala Enok.

14. Grafik Bulanan Kerusakan Pembangkit Tenaga Listrik 


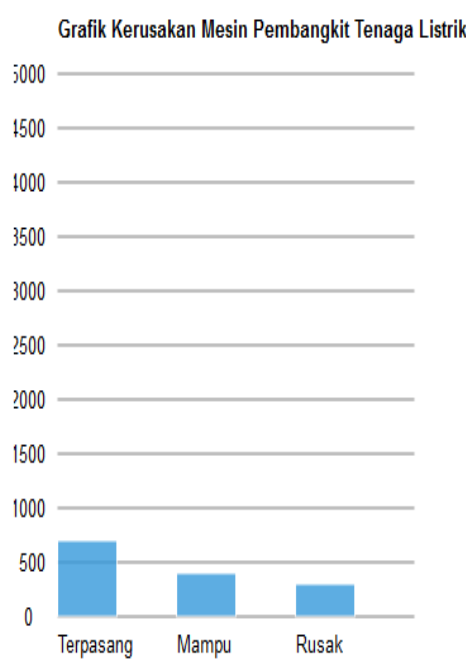

Gambar 4.17 Grafik Bulanan Kerusakan Pembangkit Tenaga Listrik

Grafik tersebut menjelaskan jumlah aset setiap bulan yang terpasang, masih mampu, dan mengalami kerusakan pada PT. PLN Rayon Kuala Enok.

\section{DAFTAR PUSTAKA}

Prakoso, Bimo Seto, dkk., (2008), Analisis dan Perancangan Sistem Informasi Akademik dengan Studi Kasus pada Sekolah Menengah Atas Terpadu (SMAT) Krida Nusantara, Jurnal Sistem Informasi, Bandung.

G.A. Gorry and M.S. Scott, A Framework fo r Management Information Systems, Slo an Management Review, 13(1), Fall 197 $1,55-70$

Taufiq Rohmat.2014.Sistem Informasi Manajemen. Graha Ilmu : Yogyakarta.

Nugroho, Bunafit. Latihan Menbuat Aplikasi Web PHP dan MySQL dengan dreamweaver $M X(6,7,2004)$ dan 8. Yogyakarta, 2008.

S.Kom, Soropi. Step by Step CMS Mambo.Jakarta, 2008.

Nugroho, Bunafit. Aplikasi Pemrograman Web Dinamis dengan PHP dan MySQL. Yogyakarta,2009.

Sutabri, Tata., Analisis Sistem Informasi, Andi, 2012

Ladjamudin, Al-Bahra Bin. Analisis dan Desain Sistem Informasi. Yogyakarta, 2005.
Horton William. 2000. Designing Web Based

Training.Canada:John Wiley\&Sons

Soeherman, Bonnie(dkk). Designing Information System. Jakarta, 2008.

URL : http://elib.unikom.ac.id/ 